\title{
Plasma cytokine profiles following subcutaneous implantation of titanium in mice
}

\author{
Takashi Oda $^{1,2^{*}}$, Hodaka Sasaki ${ }^{1,2}$, Taichi Ito ${ }^{1,2}$, Hideshi Sekine ${ }^{2,3}$, Tetsuo Kato $^{2,4}$, Masao Yoshinari ${ }^{2}$, \\ Yasutomo Yajima ${ }^{1,2}$ \\ ${ }^{1}$ Department of Oral and Maxillo-Facial Implantology, Tokyo Dental College, Chiba, Japan \\ ${ }^{2}$ Division of Oral Implants Research and HRC7, Oral Health Science Center, Tokyo Dental College, Chiba, Japan \\ ${ }^{3}$ Department of Oral and Maxillo-Facial Implantology, Tokyo Dental College, Tokyo, Japan \\ ${ }^{4}$ Laboratory of Chemistry, Tokyo Dental College, Tokyo, Japan \\ Email: ${ }^{*}$ odatakashi@tdc.ac.jp
}

Received 29 June 2013; revised 5 August 2013; accepted 23 August 2013

Copyright (C) 2013 Takashi Oda et al. This is an open access article distributed under the Creative Commons Attribution License, which permits unrestricted use, distribution, and reproduction in any medium, provided the original work is properly cited.

\begin{abstract}
Aims and Objectives: The purpose of this study was to investigate the influence of a titanium implant on immune response in mouse by monitoring change in plasma cytokine profiles. Materials and Methods: C57BL/6 (type $1 \mathrm{~T}$ helper cell-predominant) and BALB/c (type $2 \mathrm{~T}$ helper cell-predominant) mice were used. Each type was divided into an experimental and a control group: in the former, pure titanium implants $(\Phi 1 \mathrm{~mm} \times 1 \mathrm{~mm})$ were inserted into the back of the mice subcutaneously; in the latter, the wound was sutured closed with no insertion of an implant. Blood samples were collected before implantation and at $3 \mathrm{hr}, 24 \mathrm{hr}, 3 \mathrm{~d}, 1 \mathrm{mo}$, and $3 \mathrm{mo}$ after implantation. Levels of IL-2, IL-4, IL-5, IL-6, IL-10, IL-12, IL-13, IL-17A, IL-23, IFN- $\gamma$, TNF- $\alpha$, and TGF- $\beta 1$ were measured by multi-analyte enzyme-linked immunosorbent assay. Results: Baseline cytokine levels were generally higher in the BALB/c mice than in their C57BL/6 counterparts. Cytokine levels showed only slight variation after implantation of titanium in either strain. No statistically significant differences in cytokine levels were detected, except for those of IL-6 and IL-10. Conclusion: The results showed that titanium implantation induced no clear Th1-, Th2-, or Th17-mediated immune response in either Th1- or Th2-predominant mice.
\end{abstract}

Keywords: Cytokines; Titanium; Immune Response; Dental Implant

\section{INTRODUCTION}

Titanium dental implants offer an important alternative to

*Corresponding author. fixed or removable prostheses. It has been reported that titanium possesses excellent biocompatibility, high resistance to ionization and does not induce an allergic immune response [1,2]. Type 1 and $2 \mathrm{~T}$ helper cells (Th1 and Th2, respectively) play an important role in the immune response. In dental clinical practice, the majority of implant patients are aged between 50 and 60 years, and many are present with systemic diseases. These problems may be autoimmune disorders, for example, in which the response will be largely Th1-mediated [3] or allergic diseases [4] or infection with the human immunodeficiency virus, in which the response will be Th2mediated [5].

Cytokines are transmitter substances that regulate cell behavior in order to maintain homeostasis, and systemic cytokine levels are closely linked to the extent of biological invasion and clinical symptoms such as inflammation [6,7]. Periodontitis has also been shown to affect cytokine levels $[8,9]$. Several studies have evaluated titanium implants after placement by collecting peri-implant mucosa and crevicular fluid samples and locally examining their relationship to cytokine levels [10-12].

To our knowledge, however, no studies to date have undertaken a systemic comparison of cytokine levels. The aim of this study was to investigate the influence of a titanium implant on the systemic immune response in mouse by monitoring change in plasma cytokine profiles.

\section{MATERIALS AND METHODS}

\subsection{Titanium}

Titanium rods $1 \mathrm{~mm}$ in diameter and $1 \mathrm{~mm}$ in length were used. The specimens were machined from comercially pure titanium (Grade 2, Kobe Steel, Japan) and their surfaces mechanically polished. All specimens were 
ultrasonically cleaned with acetone and distilled water for $10 \mathrm{~min}$, followed by sterilization in an autoclave for $10 \mathrm{~min}$ at $121^{\circ} \mathrm{C}$ before implantation. The specimens were then aseptically stored in desiccators for approximately 1 week.

\subsection{Animal Model}

The experimental animals comprised 20 C57BL/6 mice with predominantly Th1-mediated immunity and 20 $\mathrm{BALB} / \mathrm{c}$ mice with predominantly Th2 (humoral)-mediated immunity [13]. All 40 mice were males aged 5 weeks and weighing 18 - 23 g each (Sankyo Labo Service Corporation, Inc., Tokyo, Japan). Each strain was equally divided into an experimental group $(n=10)$ and control group $(n=10)$. After inhalation anesthesia with ether, all the mice were intraperitoneally anesthetized with $3 \mathrm{ml}$ sodium pentobarbital diluted 10-fold with physiological saline. The back of each mouse was shaved and cleaned with $70 \%$ ethanol before surgery. In the experimental groups, a $10-\mathrm{mm}$ dorsal incision was made with a scalpel and 5 pieces of pure titanium subcutaneously inserted into the wound, which was then sutured closed with 2 stitches. In the control groups, an incision was made in the same manner and the wound then sutured closed without inserting a titanium implant.

Blood samples were obtained from the orbital vein plexus with a Pasteur pipette before implantation and at 3 $\mathrm{hr}, 24 \mathrm{hr}, 3 \mathrm{~d}, 1 \mathrm{mo}$, and $3 \mathrm{mo}$ after implantation. The samples were inserted in a microfuge tube containing heparin and immediately centrifuged for $10 \mathrm{~min}$ at 1000 $\times \mathrm{g}$ to isolate plasma, which was then stored at $-20^{\circ} \mathrm{C}$ until use. This study protocol was approved by the Animal Care and Use Committee of Tokyo Dental College (approval number: 223003).

\subsection{Cytokine Profiles}

Cytokine profiling of each plasma sample was performed by analyzing a panel of 12 cytokines (interleukin (IL)-2, IL-4, IL-5, IL-6, IL-10, IL-12, IL-13, IL-17A, IL-23, IFN- $\gamma$, TNF- $\alpha$, and TGF- $\beta 1$ ) using the Mouse Th1/Th2/ Th17 Cytokines Multi-Analyte ELISArray ${ }^{\mathrm{TM}}$ Kit (MEM003A, SABiosciences Corporation, Frederick, MD, USA). Tests were carried out according to the manufacturer's protocol. Briefly, $50 \mu \mathrm{l}$ each plasma sample was added to each well of the ELISA Array plate. The plate was gently shaken or tapped for $10 \mathrm{sec}$, incubated for $2 \mathrm{hr}$ at room temperature (rt), and then washed in the washing buffer provided 3 times. Fifty microliters Detection Antibodies was added to each well and incubated for $1 \mathrm{hr}$ at rt. After washing 3 times again, $100 \mu \mathrm{l}$ AvidinHRP solution was added to each well and incubated for $30 \mathrm{~min}$ at rt. Finally, after washing 4 times, $100 \mu \mathrm{l} \mathrm{De}-$ velopment Solution was added to the wells. After $15 \mathrm{~min}$,
$100 \mu \mathrm{l}$ Stop Solution was added to each well. Cytokine levels were evaluated by measuring absorbance at 450 $\mathrm{nm}$ using a microplate reader (SpectraMax ${ }^{\circledR}$, Molecular Devices Japan, Tokyo, Japan). The respective values were expressed using the following equation.

\section{Sample values - negative control values}

Positive control values - negative control values $\times 100(\%)$

Data represent the mean \pm standard deviation (SD) from 10 to 15 mice.

\subsection{Statistical Analysis}

The Mann-Whitney $U$-test was used to assess inter-strain differences in baseline cytokine production and to compare the control and experimental groups. The Tukey multiple comparison test was used to compare the data and change with time following a two-way analysis of variance (ANOVA). Data were analyzed using the software program SPSS (version 11.0.1 J for Windows XP; SPSS Inc., Chicago, IL).

\section{RESULTS}

\subsection{Condition of Mice}

No significant difference was found in body weight between the experimental and control group mice (data not shown). No inflammation, swelling, or redness in the wound surface were observed macroscopically.

\subsection{Inter-Strain Difference in Cytokine Production}

Production of IL-2, IL-5, IL-6, IL-10, IL-13, IL-17A, IL23 , IFN $-\gamma$, and TGF- $\beta 1$ at baseline was significantly higher in the BALB/c mice than in the $\mathrm{C} 57 \mathrm{BL} / 6$ mice (Figure 1) (IL-2, IL-6, IL-10: $p<0.01$; IL-5, IL-13, IL17A, IL-23, IFN- $\gamma$, TGF- $\beta 1: p<0.05)$.

\subsection{Change in Cytokine Profiles from Baseline to 3 mo after Titanium Implantation}

IL-6 levels tended to increase over time in experimental group in both $\mathrm{C} 57 \mathrm{BL} / 6$ and $\mathrm{BALB} / \mathrm{c}$ mice, and were significantly higher than those of respective control groups at 3 mo $(p<0.05)$ (Figure 2(a)). IL-10 levels showed no change up to $1 \mathrm{mo}$, but were significantly higher in both experimental and control groups of $\mathrm{BALB} / \mathrm{c}$ mice at $3 \mathrm{mo}$ versus corresponding groups of C57BL/6 mice $(p<0.05)$ (Figure 2(b)). IL-17A levels showed no significant change with time, but slight increase occurred in $\mathrm{C} 57 \mathrm{BL} / 6$ experimental group at 1 and 3 mo (Figure 2(c)). TGF- $\beta 1$ levels showed no change with time (Figure 2(d)). Table 1 shows the cytokine levels in each group prior to baseline and at each time point 


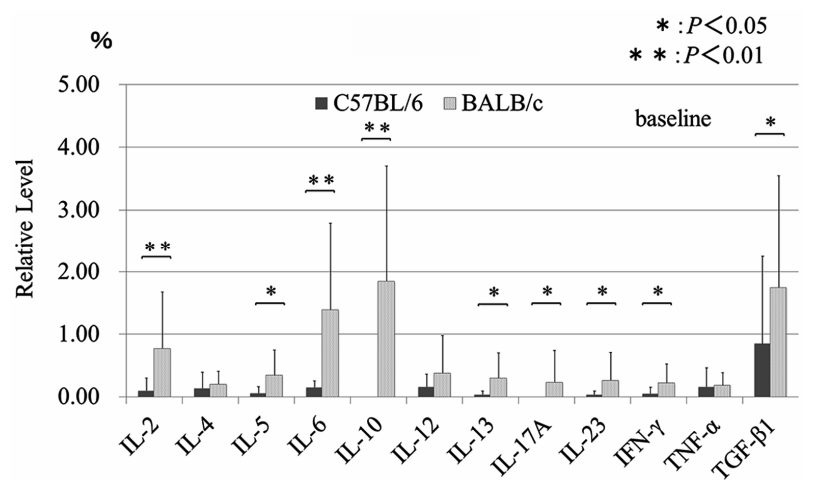

Figure 1. Inter-strain differences in baseline cytokine levels. BALB/c mice exhibited significantly higher levels of IL-2, IL-5, IL-6, IL-10, IL-13, IL-17A, IL-23, IFN- $\gamma$, and TGF- $\beta 1$ than C57BL/6 mice (IL-2, IL-6, IL-10: $p<0.01$; IL-5, IL-13, IL-17A, IL-23, IFN- $\gamma$, TGF- $\beta 1: p<0.05)$. Data represent mean \pm SD. Mann-Whitney U-test was used to assess inter-strain differences in baseline cytokine production and compare control and experimental groups. $\left({ }^{*} p<0.05,{ }^{* *} p<0.01\right)$.

after titanium implantation. Observation of changes in cytokine levels over time revealed slight variations in IL-2，IL-4，IL-5，IL-12，IL-13，IL-17A，IL-23，IFN- $\gamma$, TNF- $\alpha$, and TGF- $\beta 1$, but no statistically significant difference.

\section{DISCUSSION}

In this study, cytokine levels in BALB/c and C57BL/6 mice (Th1- and Th2-predominant, respectively, as proven by Scott et al. [13]) were investigated in order to determine the systemic effects of titanium on immune response. Th1- and Th2-predominant mice were used in this study based on the hypothesis that Th1/Th2 balance is an indicator of susceptibility to titanium.

It has been reported that Th1-related cytokines include IL-2, IL-12, IFN- $\gamma$, and TNF- $\alpha$ [14], while Th2-related cytokines include IL-4, IL-5, IL-6, IL-10, and IL-13 [15] IL-17A and IL-23 are related to Th-17 cells [16]. The present results showed that implantation of titanium induced no clear increase in Th1-, Th2-, or Th17-mediated production of cytokines, except for that of IL-6 and IL-10, in either strain of mice. The level of IL-6 was significantly higher in the experimental group of both strains than in their respective control groups at $3 \mathrm{mo}$ after implantation $(p<0.05)$. At the physiological level, IL-6 plays an important role in the immune response. However, excessive production of this cytokine induces inflammation. The levels of IL-6 detected in both experimental groups here, however, were not so high, indicating that they would be unlikely to induce inflammatory injury. Lalor et al. [17] reported that titanium debris produced by abrasion of artificial joints induced phagocytosis. Other studies investigating adjacent tissue after removal of titanium fracture plates reported delayed-type

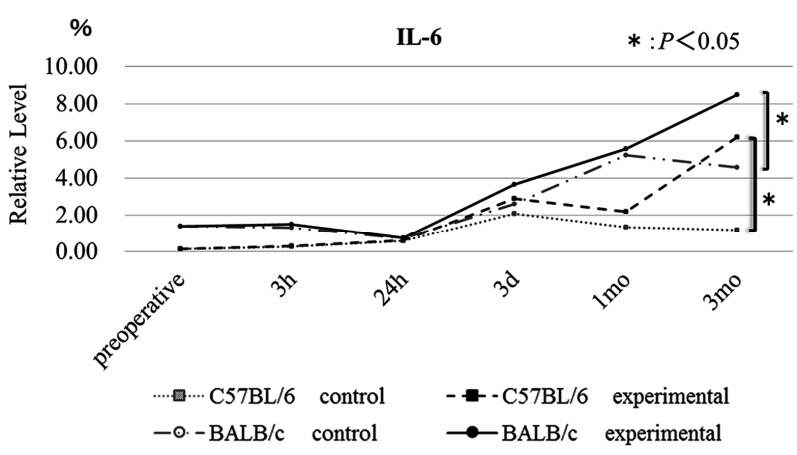

(a)

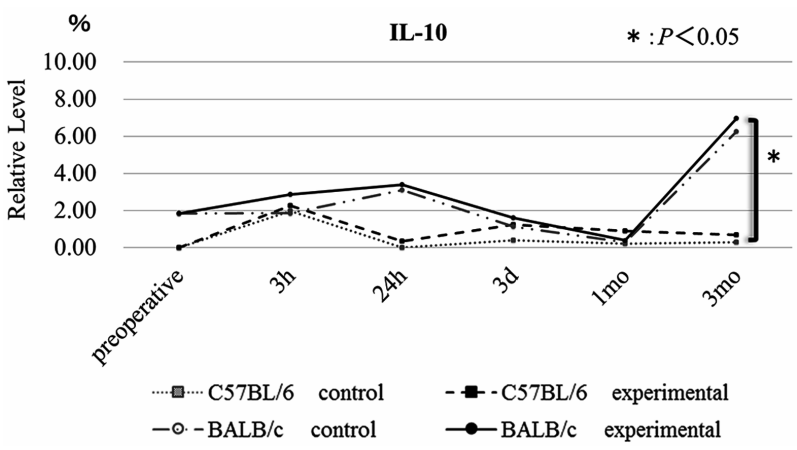

(b)

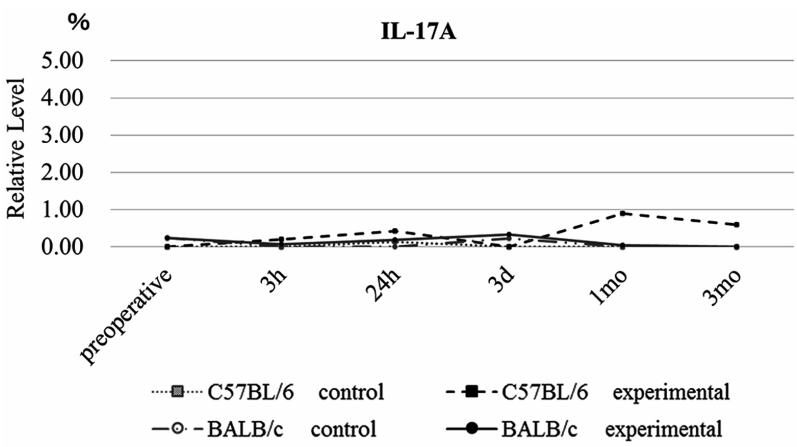

(c)

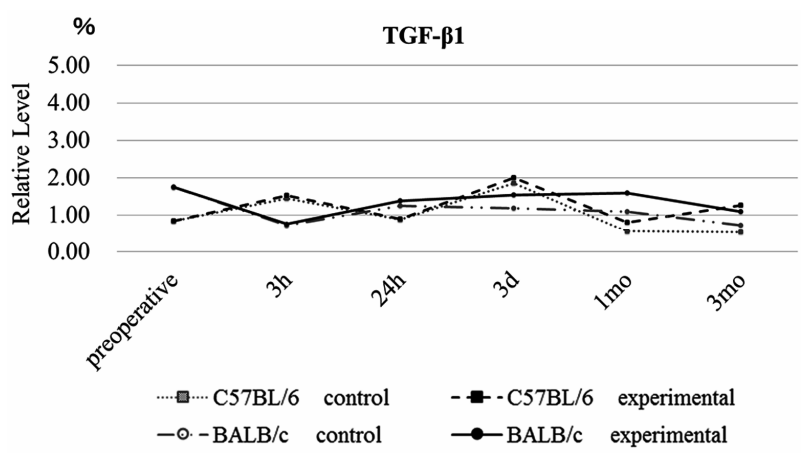

(d)

Figure 2. Change in cytokine profiles from baseline to $3 \mathrm{mo}$ after titanium implantation. a) IL-6; b) IL-10; c) IL17A and d) TGF- $\beta 1$. Data represent means with less than $20 \%$ standard deviation. Two-way ANOVA and Tukey post hoc were performed to test significance $(p<0.05)$. 
Table 1. Change in cytokine profiles from baseline to 3 mo after titanium implantation.

\begin{tabular}{|c|c|c|c|c|c|c|c|}
\hline & & Preoperative & & & topera & & \\
\hline Cytokines & Mice & & $3 \mathrm{~h}$ & $24 \mathrm{~h}$ & $3 \mathrm{~d}$ & $1 \mathrm{mo}$ & $3 \mathrm{mo}$ \\
\hline \multirow[t]{4}{*}{ IL-2 } & C57BL/6 control & 0.10 & 0.02 & 0.13 & 0.02 & 0.07 & 0.41 \\
\hline & experimental & 0.10 & 0.10 & 0.14 & 0.54 & 1.06 & 0.83 \\
\hline & BALB/c control & 0.78 & 0.17 & 0.32 & 0.18 & 0.22 & 0.34 \\
\hline & experimental & 0.78 & 0.08 & 0.36 & 0.14 & 0.23 & 0.36 \\
\hline \multirow[t]{4}{*}{ IL-4 } & C57BL/6 control & 0.14 & 0.06 & 0.10 & 0.00 & 0.00 & 0.37 \\
\hline & experimental & 0.14 & 0.13 & 0.14 & 0.00 & 0.04 & 0.40 \\
\hline & BALB/c control & 0.20 & 0.07 & 0.22 & 0.00 & 0.00 & 0.18 \\
\hline & experimental & 0.20 & 0.10 & 0.23 & 0.13 & 0.14 & 0.07 \\
\hline \multirow[t]{4}{*}{ IL-5 } & C57BL/6 control & 0.06 & 0.01 & 0.00 & 0.00 & 0.00 & 0.00 \\
\hline & experimental & 0.06 & 0.03 & 0.00 & 0.00 & 0.20 & 0.33 \\
\hline & BALB/c control & 0.35 & 0.27 & 0.17 & 0.08 & 0.36 & 0.00 \\
\hline & experimental & 0.35 & 0.20 & 0.27 & 0.49 & 0.10 & 0.14 \\
\hline \multirow[t]{4}{*}{ IL-6 } & C57BL/6 control & 0.15 & 0.28 & 0.58 & 2.09 & 1.34 & 1.19 \\
\hline & experimental & 0.15 & 0.31 & 0.60 & 2.89 & 2.19 & 6.20 \\
\hline & BALB/c control & 1.39 & 1.32 & 0.73 & 2.60 & 5.24 & 4.57 \\
\hline & experimental & 1.39 & 1.50 & 0.74 & 3.65 & 5.57 & 8.49 \\
\hline \multirow[t]{4}{*}{ IL-10 } & C57BL/6 control & 0.00 & 1.99 & 0.00 & 0.41 & 0.22 & 0.30 \\
\hline & experimental & 0.00 & 2.27 & 0.36 & 1.25 & 0.91 & 0.69 \\
\hline & BALB/c control & 1.85 & 1.86 & 3.11 & 1.13 & 0.30 & 6.26 \\
\hline & experimental & 1.85 & 2.86 & 3.40 & 1.60 & 0.39 & 6.96 \\
\hline \multirow[t]{4}{*}{ IL-12 } & C57BL/6 control & 0.16 & 0.00 & 0.00 & 0.00 & 0.07 & 0.00 \\
\hline & experimental & 0.16 & 0.53 & 0.00 & 0.00 & 0.01 & 0.27 \\
\hline & BALB/c control & 0.38 & 0.00 & 0.07 & 0.30 & 0.02 & 0.00 \\
\hline & experimental & 0.38 & 0.04 & 0.12 & 0.42 & 0.13 & 0.18 \\
\hline \multirow[t]{4}{*}{ IL-13 } & C57BL/6 control & 0.04 & 0.00 & 0.36 & 0.00 & 0.23 & 0.00 \\
\hline & experimental & 0.04 & 0.42 & 0.68 & 0.14 & 0.16 & 0.40 \\
\hline & $\mathrm{BALB} / \mathrm{c}$ control & 0.30 & 0.09 & 0.27 & 0.36 & 0.19 & 0.03 \\
\hline & experimental & 0.30 & 0.09 & 0.18 & 0.57 & 0.92 & 0.40 \\
\hline \multirow[t]{4}{*}{ IL-17A } & C57BL/6 control & 0.00 & 0.00 & 0.13 & 0.00 & 0.01 & 0.00 \\
\hline & experimental & 0.00 & 0.20 & 0.42 & 0.00 & 0.90 & 0.59 \\
\hline & $\mathrm{BALB} / \mathrm{c}$ control & 0.24 & 0.01 & 0.00 & 0.23 & 0.00 & 0.00 \\
\hline & experimental & 0.24 & 0.07 & 0.19 & 0.33 & 0.05 & 0.00 \\
\hline \multirow[t]{4}{*}{ IL-23 } & C57BL/6 control & 0.04 & 0.00 & 0.07 & 0.00 & 0.00 & 0.00 \\
\hline & experimental & 0.04 & 0.14 & 0.35 & 1.04 & 0.58 & 0.69 \\
\hline & $\mathrm{BALB} / \mathrm{c}$ control & 0.26 & 0.00 & 0.19 & 0.66 & 0.00 & 0.00 \\
\hline & experimental & 0.26 & 0.06 & 0.28 & 1.66 & 0.70 & 0.18 \\
\hline \multirow[t]{4}{*}{ IFN- $\gamma$} & C57BL/6 control & 0.05 & 0.18 & 0.00 & 0.00 & 0.01 & 0.00 \\
\hline & experimental & 0.05 & 0.35 & 0.04 & 0.02 & 0.04 & 0.25 \\
\hline & $\mathrm{BALB} / \mathrm{c}$ control & 0.22 & 0.03 & 0.09 & 0.21 & 0.00 & 0.00 \\
\hline & experimental & 0.22 & 0.18 & 0.23 & 0.33 & 0.23 & 0.73 \\
\hline \multirow[t]{4}{*}{ TNF- $\alpha$} & C57BL/6 control & 0.16 & 0.05 & 0.32 & 0.00 & 0.00 & 0.00 \\
\hline & experimental & 0.16 & 0.05 & 0.12 & 0.15 & 0.05 & 0.65 \\
\hline & $\mathrm{BALB} / \mathrm{c}$ control & 0.18 & 0.08 & 0.09 & 0.25 & 0.00 & 0.10 \\
\hline & experimental & 0.18 & 0.02 & 0.16 & 0.17 & 0.10 & 0.47 \\
\hline \multirow[t]{4}{*}{ TGF- $\beta 1$} & C57BL/6 control & 0.85 & 1.45 & 0.89 & 1.85 & 0.55 & 0.53 \\
\hline & experimental & 0.85 & 1.53 & 0.90 & 2.00 & 0.81 & 1.27 \\
\hline & $\mathrm{BALB} / \mathrm{c}$ control & 1.75 & 0.73 & 1.25 & 1.19 & 1.10 & 0.73 \\
\hline & experimental & 1.75 & 0.76 & 1.38 & 1.54 & 1.59 & 1.10 \\
\hline
\end{tabular}

(sample values - negative control values)/(positive control values - negative control values) $\times 100(\%)$. Data are averages of ten or fifteen experiments with stan- dard deviation of less than $10 \%-30 \%$. 
hypersensitivity in the vicinity of titanium based on observation of CD-4- and CD-8-positive T-lymphocytes $[18,19]$. Smith et al. [20] reported metal ions (titanium, aluminum, vanadium) in the blood of patients following insertion of titanium alloy (Ti-6Al-4V) implants. This indicates that, even though no wear particles may be produced, ionization of the titanium will still result in the presence of metal ions in the blood. Up-regulated IL-6 in mice with titanium implants may, therefore, indicate a response to the dissolution of such particles, whether they result from wear or ionization. Further study is needed, however, to clarify this point.

In the present study, IL-10 levels were significantly higher in both the experimental and control groups in $\mathrm{BALB} / \mathrm{c}$ mice than in C57BL/6 mice at $3 \mathrm{mo}(p<0.05)$. IL-10 is an anti-inflammatory cytokine produced by Th2 cells [21], which would explain why it was synthesized in greater quantities in the Th2-predominant BALB/c mice. Production of TGF- $\beta 1$, another anti-inflammatory cytokine $[22,23]$, was not affected by the titanium implant. These findings suggest that subcutaneous insertion of titanium may not be enough to trigger an immune response.

IL-17A is a member of the IL-17 family [24]. There is considerable evidence, both in human and in mouse, for the importance of IL-17 in the development and progression of inflammatory, autoimmune diseases [24] and delayed-type hypersensitivity [25]. In this study, however, IL-17A showed no change with time. It did, however, manifest a slight increase in the C57BL/6 experimental group at 1 and $3 \mathrm{mo}$. This suggests that the titanium implant had virtually no impact on IL-17A levels.

Cytokine levels were generally higher in the BALB/c mice than in their $\mathrm{C} 57 \mathrm{BL} / 6$ counterparts at baseline, but no such inter-strain differences were observed after insertion of the titanium. This outcome may be explained by the minimal systemic impact of titanium due to its low reactivity, characterized by resistance to ionization. However, the fact that some cytokines such as IL-6 showed an increase at 3 mo implies that, over the long term, titanium may have various effects systemically. Leopold et al. [26] detected titanium in the serum of a patient undergoing treatment using a titanium implant. Furthermore, Wappelhorst et al. [27] reported that titanium may be transmitted to infants via breast milk. Demand for titanium dental implants is expected to further increase in the future. Therefore, it is important to consider not only how their use can improve oral function but also their potential systemic impact. One limitation of this study was that the titanium implants were not tested in an oral environment. However, it is possible that the effects of titanium would be even greater in the oral environment, given the presence of biological factors such as saliva and bacteria.

\section{ACKNOWLEDGEMENTS}

This research was supported by the Foundation of the Japan Medical Association, by Oral Health Science Center Grant hrc7 from Tokyo Dental College, and by a "High-Tech Research Center" Project for Private Universities: matching fund subsidy from MEXT (Ministry of Education, Culture, Sports, Science and Technology) of Japan, 20062011. The authors would like to thank Associate Professor Jeremy Williams for his assistance with the English of this article.

\section{REFERENCES}

[1] Pohler, O.E. (2000) Unalloyed titanium for implants in bone surgery. Injury, 31, 7-13. doi:10.1016/S0020-1383(00)80016-9

[2] Schmidt, B.L., Perrott, D.H., Mahan, D., et al. (1998) The removal of plates and screws after Le Fort I osteotomy. Journal of Oral and Maxillofacial Surgery, 56, 184-188. doi:10.1016/S0278-2391(98)90865-5

[3] Leonard, J.P., Waldburger, K.E. and Goldman, S.J. (1995) Prevention of experimental autoimmune encephalomyelitis by antibodies against interleukin 12. The Journal of Experimental Medicine, 181, 381-386. doi:10.1084/jem.181.1.381

[4] Durham, S.R. and Till, S.J. (1998) Immunologic changes associated with allergen immunotherapy. Journal of Allergy and Clinical Immunology, 102, 157-164. doi:10.1016/S0091-6749(98)70079-X

[5] Clerici, M. and Shearer, G.M. (1993) A $\mathrm{T}_{\mathrm{H}} 1 \rightarrow \mathrm{T}_{\mathrm{H}} 2$ switch is a critical step in the etiology of HIV infection. Immunology Today, 14, 107-111. doi:10.1016/0167-5699(93)90208-3

[6] Liskmann, S., Vihalemm, T., Salum, O., et al. (2006) Correlations between clinical parameters and interleukin-6 and interleukin-10 levels in saliva from totally edentulous patients with peri-implant disease. The International Journal of Oral \& Maxillofacial Implants, 21, 543-550.

[7] Duarte, P.M., de Mendonça, A.C., Máximo, M.B., et al. (2009) Effect of anti-infective mechanical therapy on clinical parameters and cytokine levels in human peri-implant diseases. Journal of Periodontology, 80, 234-243. doi:10.1902/jop.2009.070672

[8] Birkedal-Hansen, H. (1993) Role of cytokines and inflammatory mediators in tissue destruction. Journal of Periodontal Research, 28, 500-510. doi:10.1111/j.1600-0765.1993.tb02113.x

[9] Genco, R.J. (1992) Host responses in periodontal diseases: Current concepts. Journal of Periodontology, 63, 338355. doi:10.1902/jop.1992.63.4s.338

[10] Schierano, G., Bassi, F., Gassino, G., et al. (2000) Cytokine production and bone remodeling in patients wearing overdentures on oral implants. Journal of Dental Research, 79, 1675-1682. doi:10.1177/00220345000790090701

[11] Javed, F., Al-Hezaimi, K., Salameh, Z., et al. (2011) Proinflammatory cytokines in the crevicular fluid of patients with peri-implantitis. Cytokine, 53, 8-12. 
doi:10.1016/j.cyto.2010.08.013

[12] Candel-Martí, ME., Flichy-Fernández, AJ., Alegre-Domingo, T., et al. (2011) Interleukins IL-6, IL-8, IL-10, IL-12 and periimplant disease. Medicina Oral, Patología Oral y Cirugia Bucal, 16, 518-521. doi: $10.4317 /$ medoral.16.e518

[13] Scott, P. (1991) IFN- $\gamma$ modulates the early development of $\mathrm{Th} 1$ and $\mathrm{Th} 2$ responses in a murine model of cutaneous leishmaniasis. The Journal of Immunology, 147, 31493155 .

[14] Chensue, S.W., Ruth, J.H., Warmington, K., et al. (1995) In vivo regulation of macrophage 11-12 production during type 1 and type 2 cytokine-mediated granuloma formation. The Journal of Immunology, 155, 3546-3551.

[15] Haraguchi, S., Good, R.A., James-Yarish, M., et al. (1995) Differential modulation of Th1- and Th2-related cytokine mRNA expression by a synthetic peptide homologous to a conserved domain within retroviral envelope protein. Proceedings of the National Academy of Sciences, 92, 3611-3615. doi:10.1073/pnas.92.8.3611

[16] Tallima, H., Salah, M., Guirguis, FR., et al. (2009) Transforming growth factor-b and Th17 responses in resistance to primary murine schistosomiasis mansoni. Cytokine, $\mathbf{4 8 ,}$ 239-245. doi:10.1016/j.cyto.2009.07.581

[17] Lalor, P.A., Revell, P.A., Gray, A.B., et al. (1991) Sensitivity to titanium, a cause of implant failure? The Bone \& Joint Journal, 73, 25-28.

[18] Hunt, J.A., Williams, D.F., Ungersbock, A., et al. (1994) The effect of titanium debris on soft tissue response. Journal of Materials Science: Materials in Medicine, 5, 381-383. doi:10.1007/BF00058968

[19] Katou, F., Andoh, N., Motegi, K., et al. (1996) Immunoinflammatory responses in the tissue adjacent to titanium miniplates used in the treatment of mandibular fractures. Journal of Cranio-Maxillofacial Surgery, 24, 155-162.

\section{doi:10.1016/S1010-5182(96)80049-7}

[20] Smith, D., Lugowski, S., McHugh, A., et al. (1997) Systemic metal ion levels in dental implant patients. The International Journal of Oral \& Maxillofacial Implants, 12, 828-834.

[21] Prete, G.D., Carli, M.D., Almerigogna, F., et al. (1993) Human IL10 is produced by both type 1 helper (Thl) and type 2 helper (Th2) $\mathrm{T}$ cell clones and inhibits their antigen-specific proliferation and cytokine production. The Journal of Immunology, 150, 353.

[22] Groux, H., O'Garra, A., Bigler, M., et al. (1997) ACD4+ $\mathrm{T}$-cell subset inhibits antigen-specific $\mathrm{T}$-cell responses and prevents colitis. Nature, 389, 737-742. doi: $10.1038 / 39614$

[23] Opal, S.M. and DePalo, V.A. (2000) Anti-inflammatory cytokines. Chest, 117, 1162-1172. doi:10.1378/chest.117.4.1162

[24] Afzali, B., Lombardi, G., Lechler, RI., et al. (2007) The role of T helper 17 (Th17) and regulatory T cells (Treg) in human organ transplantation and autoimmune disease. Clinical \& Experimental Immunology, 148, 32-46. doi:10.1111/j.1365-2249.2007.03356.x

[25] Yamashita, K., Sakai, M., Takemoto, N., et al. (2009) Attenuation of delayed-type hypersensitivity by fullerene treatment. Toxicology, 261, 19-24. doi:10.1016/j.tox.2009.04.034

[26] Leopold, S.S., Berger, R.A., Patterson, L., et al. (2000) Serum Titanium level for diagnosis of a failed, metalbacked patellar component. The Journal of Arthroplasty, 15, 938-943. doi:10.1054/arth.2000.6632

[27] Wappelhorst, O., Kühn, I., Heidenreich, H., et al. (2002) Transfer of selected elements from food into human milk. Nutrition, 18, 316-322. doi:10.1016/S0899-9007(01)00798-5 